\title{
複雑な相互作用ネットワークを導入した人工市場 シミュレーション
}

\section{Artificial Market Simulation with Embedded Complex Network Structures}

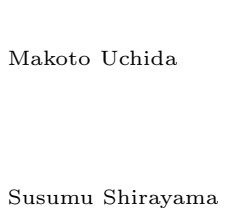

\author{
東京大学大学院工学系研究科 \\ School of Engineering, the University of Tokyo \\ uchida@race.u-tokyo.ac.jp
}

東京大学人工物工学研究センター

Research into Artifacts, Center for Engineering (RACE), the University of Tokyo sirayama@race.u-tokyo.ac.jp

keywords: complex networks, network effect, artificial markets, multi-agent simulations, communication serivce markets

\section{Summary}

We investigate a factor of the 'network effect' that affects on communication service markets by a multi-agent based simulation approach. The network effect is one of a market characteristic, whereby the benefit of a service or a product increase with use. So far, the network effect has been studied in terms of macroscopic metrics, and interaction patterns of consumers in the market were often ignored. To investigate an infulence of structures of the interaction patterns, we propose a multi-agent based model for a communication serivce market, in which embedded complex network structures are considered as an interaction pattern of agents. Using several complex network models as the interaction patterns, we study the dynamics of a market in which two providers are competing. By a series of simulations, we show that the structural properties of the complex networks, such as the clustering coefficient and degree correlations, are the major factors of the network effect. We also discuss an adequate model of the interaction pattern for reproducing the market dynamics in the real world by performing simulations exploiting with a real data of social network.

\section{1. 緒言}

多数のプレイヤーの相互作用から生じる市場現象は， しばしば複杂隹で非線形な振る舞いを呈する．乥れを適切 に分析，理解し，予測，制御することは，効率的な市場 の構築や，効果的な経済政策やマーケッティング施策の 立案という点で重要である．複䧱な市場現象を計算機シ ミュレーションの立場から分析する手法のひとつとして， 人工市場シミュレーションがある . 人工市場とは , 市場 における主体 (企業, 消費者など) をエージェントに見 立てたマルチェージェントモデルとして計算機上に実装 された仮想的な市場である [和泉 03] . 樣々な設定でのシ ミュレーションを行うことで，あるパラメータ設定にお ける現象の観察や，ある特定の現象の要因を探るなどの 分析ができる .

本研究では, 市場現象の一つとして知られる ‘ネット ワーク外部性” (もしくは , ‘ネットワーク効果') に着目す る.ネットワーク外部性とは , 同じ財やサービスの利用者 が多いほど，消費者が产の財やサービスの消費から得ら
れる効用が高まる効果である $[$ Katz 85] . ネットワーク外 部性が作用する市場では，よく売れている財やサービス を選ぶことの効用がより高くなり，さらに关の財やサー ビスが選択されやすくなるという正のフィードバックが㗢 く [Arthur 90] . 兴のため, ネットワーク外部性はデファ クト・スタンダードとなる規格の出現や，ある財やサー ビスがー人勝ち (Winner-Takes-All) するなどの現象の 要因であると考えられている [Arthur 96] . 実際に , ネッ トワーク外部性市場をモデル化した分析に関する研究は 多い [Church 92, Katz 92, Arthur 93, Wendt 00, Frels 03, Weitzel 02, Khalak 03, Phan 03, 川村 05, 金子 06].

人工市場シミュレーションを用いる研究では,利用者間 のミクロレベルでの相互作用を直接的にモデル化し , マル チェージェントシミュレーションを用いて市場の局所性や シェアの逆転現象などが再現されている. [井庭 01, 井庭 03] .このような取り組みの中では, 相互作用を行うエー ジェント空間構造の影響力指摘されている。実際，Leeら は利用者数やシェアのようなマクロ統計量に過度に注目 
し，利用者間のネットワーク構造を見落とすことは，分 析を見誤ることにつながると指摘している [Lee 06] . 一 方で , 現実の社会的なコミュニケーションネットワーク は, 規則的でも完全に無秩序でもない, 複雑な構造を有 することが明らかにされており [Newman 06]，弚のよう な構造はネットワーク外部性の作用に重要な影響を与え るものと考えられる .

本研究の目的は, 人工市場シミュレーションの手法を 用いて, ネットワーク外部性の要因を分析することであ る . 電話やメールに代表されるコミュニケーションサー ビスの市場を題材とし，エージェントのコミュニケーショ ンネットワークの構造に特に着目した人工市場モデルを 構築し，作用するネットワーク外部性の影響について調 べる . 具体的には , 複雑ネットワークモデルの導入によっ て相互作用の空間構造を制御したネットワーク上で利用 者をエージェントとしてモデル化した人工市場モデルの 構筑およびシミュレーションを行い, エージェントの空間 構造とサービス事業者のシェアとの関係を分析する．光 の結果から，ネットワーク外部性の効果と，ネットワー ク構造の統計的指標の特徵との関係性を明らかにするこ とを目的とする．さらに，現実世界のコミュニケーショ ンネットワークの一例として，Eメールによるコミュニ ケーションネットワークの実データを用いて提案モデル による数值実験を行い，弚の結果から現実の市場におけ るネットワーク構造の適切なモデルについて考察する．

\section{2. モ デル}

本論文では，ネットワーク外部性が作用する市場の例 として, 携帯電話やメール, ショートメッセージ等の利 用を念頭においたコミュニケーションサービスの市場を 対象とする.2つの事業者がシェアを競争している市場を 想定し，弚のどちらかを利用する利用者の意思決定のモ デルと, コミュニケーションのネットワーク構造を，人 工市場のモデルとして考える

\section{$2 \cdot 1$ 効用関数と利用者の意思決定モデル}

本論文では利用者の効用関数として金銭コストに関す る部分のみを考える。これは，例えば携帯電話サービス を考えた場合，通話料や初期費用の負担といった直接的 な費用のモデル化に相当する .

利用費用はサービスの利用量と，コミュニケーション 相手の人数に依存するものとし，利用者は金銭コストを 最小化するように事業者を選択するものとする .このと き, 単位期間あたりの相手 1 人あたりのサービス利用量
を $x_{i}$ とするとき，利用者 $i$ の効用関数 $f$ を次式とする .

$$
\begin{aligned}
& f\left(x_{i}, \alpha^{S}, \alpha^{D}, k_{i}^{S}, k_{i}^{D}, \delta\right) \\
=- & \min \left\{\left(\alpha^{S} k_{i}^{S}+\alpha^{D} k_{i}^{D}\right) x_{i},\right. \\
& \left.\left(\alpha^{S} k_{i}^{D}+\alpha^{D} k_{i}^{S}\right) x_{i}+\delta\right\},
\end{aligned}
$$

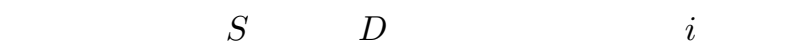
事業者，および違う事業者をあらわす.$k_{i}^{S}$ および $k_{i}^{D}$ は， 利用者 $i$ の周囲で, $i$ と同じ , および異なる事業者を利用 する利用者の数である . $\alpha^{S}$ は同じ事業者を利用する相手 に対する単位量あたりのサービス利用費用， $\alpha^{D}$ は異な る事業者を利用する相手に対する単位量あたりのサービ ス利用費用を表す．本論文では $\alpha^{S}<\alpha^{D}$ なる定数であ ることを仮定する． $\delta$ は異なる事業者に変更するための 乗り換え費用であり，すべての利用者に対して等しい定 数とする

このとき, $x_{i}$ の決定方法として , 次の 2 種類のルールを 考える.第一のモデルでは, 相手 1 人あたりのサービス利 用量は全利用者における平均 $\bar{X}$ に等しいものと仮定する . このとき，利用者 $i$ の総サービス利用量は $\left(k_{i}^{S}+k_{i}^{D}\right) \bar{X}$ となる.第二のモデルでは, 各々の利用者の総サービス利 用量 $X_{\text {total }}$ か泟規分布に従うものと仮定する .すなわち， 相手 1 人あたりの利用量 $x_{i}$ は $x_{i}=X_{\text {total }} /\left(k_{i}^{S}+k_{i}^{D}\right)$ と なる.以降，前者をモデル I , 後者をモデル II と呼ふぶ*1． 実際の携帯電話利用者の利用状況を調査した研究によれ ば, 相手先が多い (次数が高い) 利用者ほど, 相手 1 人 あたりの平均通話時間は単調に減少するという報告があ る [佐々木 05] .この文献では，これを時間的な制約等に より通話相手が多いと一人あたりに対してかけられる時 間が減少するためであると考察しているが，定性的な報 告にとどまり，具体的な関数形は明らかにされていない， 乥こで, 本論文ではこの要素を単純化し，モデル I は次数 の増加による平均通話時間の減少を無視したモデル，モ デル II は次数の増加による平均通話時間の減少を, 次数 に反比例する形で取り入れたモデルであるとして考える .

これらのモデルに従い，ある利用者 $i$ は効用関数を最大 化するように，現在の事業者を利用し続けるか，異なる事 業者に乗り換えるかの意思決定を行う . 具体的には，ある 時刻 $t$ にエージェントを 1 つランダムに選択し，式(1)に 従って $f$ を最大化するように, 利用する事業者を変更す るか否かを決定する .このとき,意思決定と事業者の変更 は非同期的に行う．すなわち，あるエージェントは全ェー ジェント数 $N$ よって正規化した時間ステップ $T=t / N$ に 1 回の割合で, 事業者の選択の意思決定と变更を行う．

$2 \cdot 2$ ネットワークモデル

利用者のコミュニケーションの空間構造として, 図 1 に模式的に示すようにノードとエッジによって表現され

$* 1$ モデル II において , 〈k〉 をコミュニケーション相手の数の平 均 (平均次数) とすれば, $X_{\text {total }}$ の平均は $\bar{X}\langle k\rangle$ と等しい. 
(A)

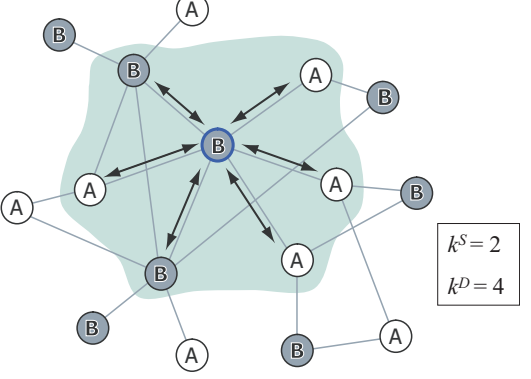

図 1 コミュニケーションネットワークの概念図

るネットワーク構造を考える.图 1 では, 中央の○で示 した利用者は, 事業者 B を利用していて, エッジの数が 6 (次数が 6 ) であり, 事業者 $\mathrm{A}$ の利用者 4 人, 事業者 $\mathrm{B}$ の利用者 2 人と隣接し, 恒常的にコミュニケーション を取っていることを表している

近年の多くの研究により，現実の社会的ネットワークで は, へきき乗分布的な次数分布，高いクラスタリング係数*2， 短い平均経路長 $* 3$, 正の次数相関*4 など, 特徵的ないくつ かの性質を持つことが明らかにされつつある [Boccaletti 06, Newman 06].実際の携帯電話利用者の調査でも，利 用者の次数分布はピークを持たずに高次の部分が厚い， いわゆるへビーテイルな確率分布になることが報告され ている[佐々木 05] .

そこで, 本論文ではこのような空間構造を, 複雑ネッ トワークモデルによって与える .ネットワークモデルの 導入によってコミュニケーションネットワークの統計的 性質を変化させながら, ネットワークの構造と, 弚の結果 現れるネットワーク外部性の効果との関係を調べる . 本 論文では，格子 , ランダムネットワーク [Erdös 59]，WS モデル [Watts 98] , BA モデル [Barabási 99] , KE モデ ル [Klemm 02] , CNN モデル [Vázquez 03] の 6 種類の ネットワークモデルを用いた . 以下 , 各モデルについて 述べる。

\section{$\S 1$ 格子 (Lattice)}

格子モデルは，規則的に配置した近隣 $n$ ノードと接続 した正則なネットワークである.このとき，すべてのノー ドの次数は一樣となり, 平均経路長 $L$ はノード数 $N$ に

\footnotetext{
$* 2$ クラスタリング係数 $C$ とは , あるノードの隣接ノード間に エッジが存在する確率とであり，以下の式で定義される .ここ で $N$ はノードの総数 $, k_{i}, E_{i}$ は光れ光れノード $i$ の次数と, ノード $i$ に隣接するノードの相互間に存在するエッジの総数を 表す.

$$
C=\frac{1}{N} \sum_{i} \frac{2 E_{i}}{k_{i}\left(k_{i}-1\right)}
$$

$* 3$ 平均経路長 $L$ とは, 任意の 2 ノード間の最短パスにエッジ がくつ存在するかという最短パス距離をすべてのノードの組 み合わせについて平均したものである

*4 次数相関とは, あるエッジの両端のノードの次数のピアソン 相関係数である.正の次数相関とは, 次数の高いハブになって いるノード同士が互いに接続している，あるいは次数の低い ノード同士が互いに接続している傾向にあることを意味する。
}

表 1 ネットワークモデルの構造的性質.下段カッコ内は $N=3600$ ， $\langle k\rangle=10$ の場合の実測値 .

\begin{tabular}{c|cccc}
\hline & 次数分布 & $L$ & $C$ & 次数相関 \\
\hline Lattice & 一樣 & 大 & 大 & ナシ \\
& & $(180)$ & $(0.67)$ & \\
$\mathrm{ER}$ & 標準分布的 & 小 & 小 & ナシ \\
& & $(3.80)$ & $(0.0027)$ & \\
$\mathrm{WS}$ & 標準分布的 & 小 & 大 & ナシ \\
& & $(4.62)$ & $(0.35)$ & \\
$\mathrm{BA}$ & ベき乗分布的 & 小 & 小 & ナシ \\
& & $(3.36)$ & $(0.015)$ & \\
$\mathrm{KE}$ & ベき乗分布的 & 小 & 大 & 負 \\
& & $(4.37)$ & $(0.65)$ & \\
$\mathrm{CNN}$ & ベき乗分布的 & 小 & 大 & 正 \\
& & $(5.14)$ & $(0.40)$ & \\
\hline
\end{tabular}

比例する . またクラスタリング係数 $C$ は $N$ によらず定 数のオーダーとなり比較的大きくなる.

\section{$\S 2$ ランダムネットワーク (ER)}

ランダムネットワーク (Erdös-Renyí モデル , 以下 ER モデルと呼ぶ) [Erdös 59] は , ノード数とエッジ数を固定 し，エッジをランダムに配置して生成するネットワークで ある.ネットワーク外部性に関する従来研究ににおいてネ ットワーク構造に着目したものでは, ランダムネットワー クを考えているものが多い [Arthur 93, Frels 03, Khalak 03]. ランダムネットワークでは, 次数分布は平均次数付 近にピークを持つポワソン分布となり， $L$ は $\log N$ に比 例し， $C$ は $N$ の増加とともにゼロに近づく .

\section{$\S 3$ WS モデル}

WS (Watts-Strogatz) モデル [Watts 98] は, 格子とラ ンダムネットワークの中間のモデルであり，特に 'smallworld モデル として知られる.WS モデルは，格子の エッジをある確率 $p$ でランダムに繋ぎかえることで生成 する．繁ぎかえられたエッジは，格子の中で「ショート カット」の役割を果たし，これが $L$ をさくする．本論 文では, 繁ぎかえの確率 $p$ を 0.1 としたものを用いる .

\section{$\S 4$ スケールフリーネットワーク}

現実の社会的ネットワークの主要な特徵の1つとして， 各ノードに接続するエッジの次数分布 $P(k)$ が幕乗分布 $P(k) \propto k^{-\gamma}$ に従うことが多くの事例で観察されており， 「スケールフリー」という性質として着目されている．ス ケールフリーの性質を持つネットワークモデルとして , 本 論文では BA (Barabási-Albert) モデル [Barabási 99]， KE (Klemm-Eguílz) モデル [Klemm 02] および CNN (Connecting Nearest Neighbor) モデル [Vázquez 03] の各モデルを扱う．これらは順次新たなノードか誕生し て，既存のノードと接続するという「成長」のメカニズム を，異なる側面からモデル化したものである．いずれも

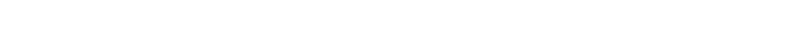
れ異なる特徵を持つことが知られている．これらのネッ トワークモデルの性質は, 表 1 のようにまとめられる . 


\section{3. 計 算 機 実 験}

\section{$3 \cdot 1$ 準安定状態の発現}

前章で述べた意思決定モデルおよび相互作用のネット ワークモデルに従い , マルチェージェントシミュレーショ ンによる数值実験により，2 事業者の競争を模擬した市場 のダイナミクスを計算機シミュレーションによって調べ る.初期状態として，2つの事業者が市場全体の $50 \%$ ず つのシェアをランダムにもつ状態を与える . このとき, 2 つの事業者の $\alpha^{S}, \alpha^{D}, \delta$ のパラメータはすべて等しく設 定した .すなわち，2つの事業者におけるサービスやコス 卜は対称的で，差異がない状態を考える．これは，サー ビスの品質や価格が等価であるにもかかわらず，市場に 内在するコミュニケーションの空間構造に起因した外部 性が引き起こされるシナリオを意図している .

図 2 および図 3 に , モデル I およびモデル II によるシ ミュレーションにおける事業者のシェアの典型的な時間 発展を示す.エージェント数は $N=3600$ とした . 図か らわかるように , モデル I , モデル II どちらの意思決定 モデルにおいても，初期状態におけるシェアが等しいに もかかわらず , 利用者のネットワーク上の分布の違いに よっていずれかの事業者が次第に卓越する準安定状態に 達する . 2 つの事業者のパラメータはすべて同一である ので、どちらが」卓越したか，という点は意味を持たな いが, 十分時間が経過した後に卓越している事業者 (勝 者:winner と呼ぶ）のシェアが収束する值は試行によら ず一定の範囲に収まることを確認した . 利用者の意思決 定モデルを考慮すると，同じ事業者を選択する方が効用 が高まり，さらに光の事業者が選択されやすくなること を意味する．光こで, 本論文では, 勝者の市場シェアの 大きさを市場に作用したネットワーク外部性の強さの尺 度であると考える．

エージェントのコミュニケーション量に正規分布によっ て不均一性を導入したモデル II のほうが, モデル I より 安定までに長いステップを要する . 以降 , モデル I では， シェアの安定する $T=t / N=45$ ステップ以降の 5 ステッ プ $(T=46$ から $T=50)$ における平均を , モデル II で は $T=t / N=450$ ステップ以降の 50 ステップ $(T=451$ から $T=500)$ における平均を，乥れ光れ終状態におけ るシェアとする . また , 各パラメータについて , モデル I では 500 回 , モデル II では 100 回の試行における平均 値を結果として採用する。

\section{$3 \cdot 2$ ネットワークモデルを用いたシミュレーション}

図 4 および図 5 に，モデル I の意思決定モデルによる， 最終状態における勝者のシェアを，乗り換えコス卜 $\delta$ に 対する関数として示す. 図 4 には $\langle k\rangle$ による比較, 図 5 には, $\bar{X}$ による比較を示す . 図中で, 誤差棒は 500 回の 試行における標準偏差を示している . 以下 , 背後のネッ トワーク構造の違いによる結果に対する影響に着目する .
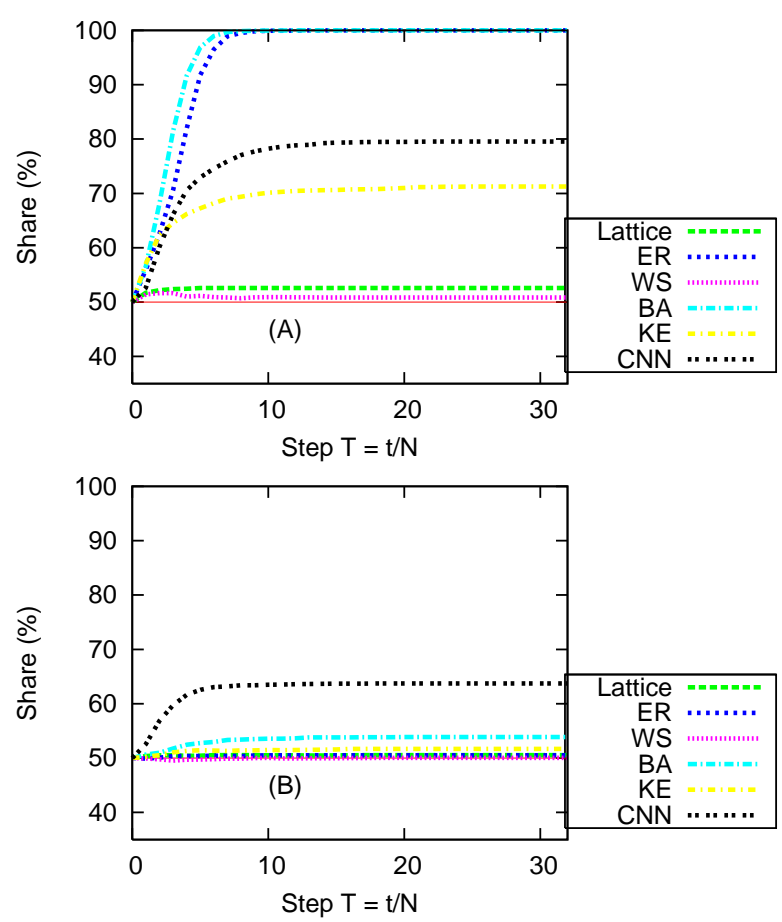

図 2 典型的な 1 回の試行における,勝者となる事業者のシェアの時 系列変化 .(モデル $\mathrm{I},\langle k\rangle=10, \bar{X}=100, \alpha_{S}=20, \alpha_{D}=25$, (A) $\delta=500,(\mathrm{~B}) \delta=2500$ )
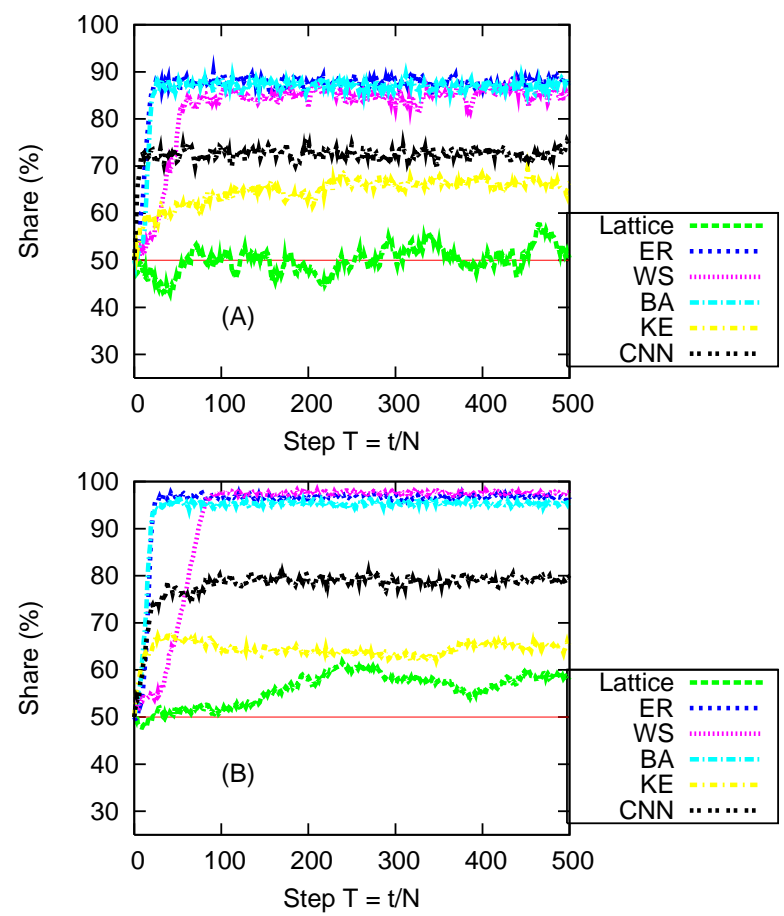

図 3 典型的な 1 回の試行における, 勝者となる事業者の シェアの時系列変化 . ( モデル II, $\langle k\rangle=10, X_{\text {total }}=$ $N(100\langle k\rangle, 100\langle k\rangle / 3), \alpha_{S}=20, \alpha_{D}=25$, (A) $\delta=500$, (B) $\delta=2500$ )

初期状態におけるシェアを $1: 1$ としたので， $\delta \rightarrow \infty$ とすると初期状態から動かず, 勝者のシェアは $50 \%$ に近 ブくことはモデルより自明である .ところが , $\delta$ が小さ 

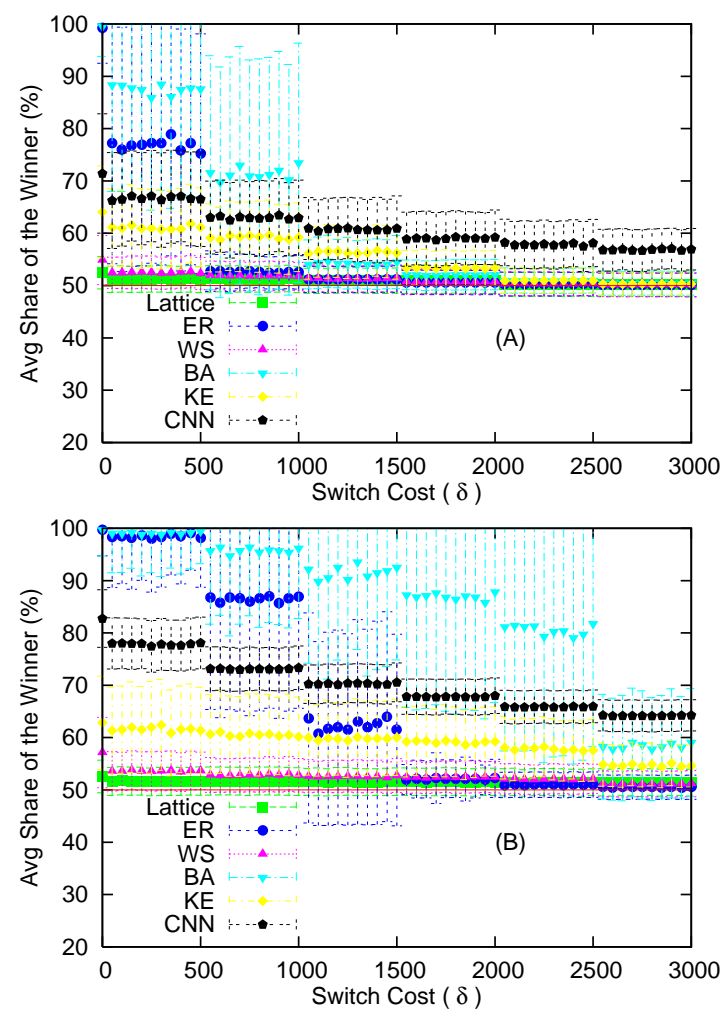

図 4 準安定状態における勝者のシェア.(モデル I, 誤差棒は 500 回の試行における標準偏差をあらわす . $\bar{X}=100, \alpha_{S}=20$, $\alpha_{D}=25$, (A) $\langle k\rangle=8$, (B) $\langle k\rangle=10$.)

い領域では，背後のネットワーク構造に強く依存した自 明ではない値をとる.$\delta$ がさい領域では , ER モデルと $\mathrm{BA}$ モデルにおいて , 勝者のシェアが大きくなり，ネッ トワーク外部性の効果か強まる．これらに共通する性質 として , クラスタリング係数が低い点を指摘することが できる，一方， $\delta$ が大きい領域でも，CNN モデルでは勝 者のシェアの低下が緩やかであり，強い外部性の効果が

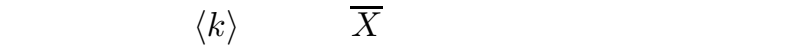
もコミュニケーションの相手 , 量ともに活発になること に相当する．炎のような場合には，同じ $\delta$ に対して外部 性の効果か強く作用する．また， $\delta=0$ の場合のシェア

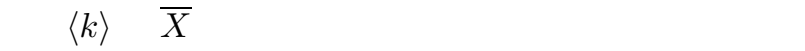
ことがわかる .

図 6 および図 7 に , モデル II の意思決定モデルによる， 最終状態における勝者のシェアを示す . 各エージェント の総コミュニケーション量 $X_{\text {total }}$ は, 平均 $\bar{X}\langle k\rangle$, 標準 偏差 $\bar{X}\langle k\rangle / 3$ の正規分布乱数により，ステップ毎に異な

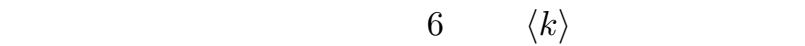
7 には，吕による比較を示した .

モデル II においても，十分大きな $\delta$ に対しては勝者の シェアは $50 \%$ に収束することはモデルより明らかである しかしながら，実験を行った $\delta$ 範囲では異なる振る舞 いか観察され，この場合も背後のネットワーク構造に強 く依存している.特に, 試行によらず一定の狭い值の範 囲に安定的に収束し，なおかつ $\delta に$ 対して安定で明確な
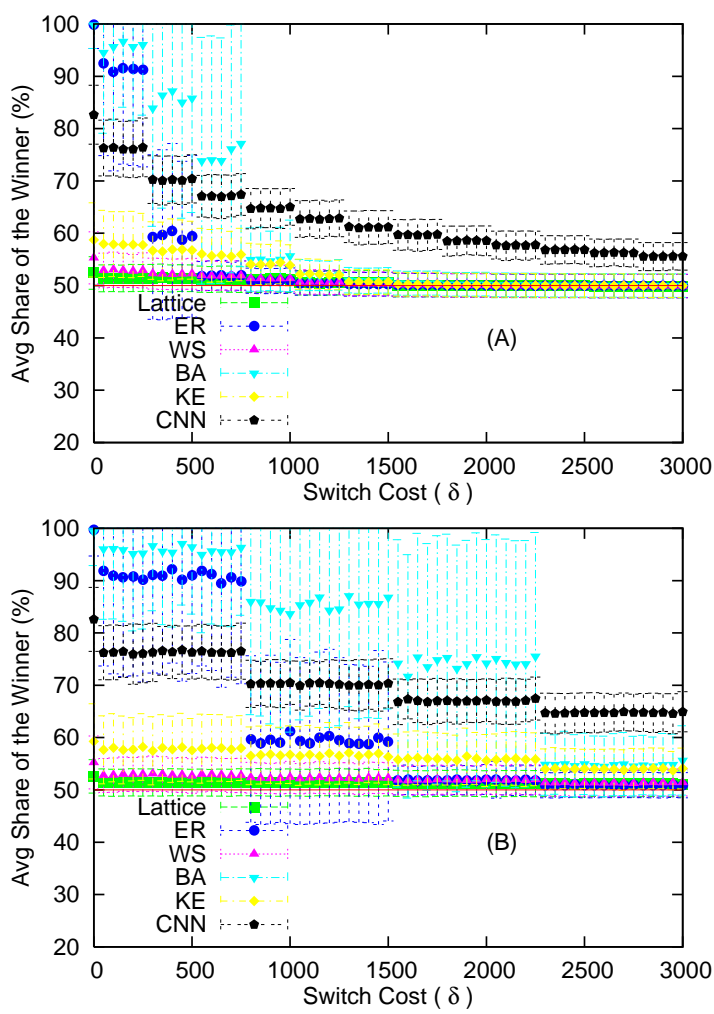

図 5 準安定状態における勝者のシェア.(モデル I, 誤差棒は 500 回の試行における標準偏差をあらわす . $\langle k\rangle=10, \alpha_{S}=20$ $\alpha_{D}=25$, (A) $\bar{X}=50$, (B) $\bar{X}=150$.)

関数関係が認められるクラスと, 試行ごとのばらつきが 大きく, $\delta$ に対して明確な関数関係を持たない不安定な クラスとの，2 つの異なる振る舞いが観察された . 以下， 本論文ではこれらのクラスを光れ光れ「安定相」と「不 安定相」と呼引゙ .

例えば，図 6(A) では, ER，BA，WS の各モデルでは， 100 回の試行で常に一定の範囲に収束し，なおかつ $\delta に$ 対して単調に増加するという安定相が発現している . 図 6(A)の WS モデルでは $\delta \simeq 1000$ の領域までは試行ごと のばらつきは生じているが， $\delta$ に対して安定的で明確な 関数関係が認められ，なおかつ，より大きな $\delta$ の領域へ 滑らかに連続することから，これも安定相に分類される と考えることができる.一方，同じ図 6(A) では，CNN， KE の各モデルでは, 試行ごとの標準偏差が大きく，な おかつ光の平均值も $\delta$ に対して安定的で明確な関係を持 たないため，不安定相に分類できる． Lattice に関して は, 誤差棒は比較的小さいものの， $\delta$ に対する安定的な 関係か弱く，不安定相に近いクラスであると考えること ができる . 安定相では, 勝者のシェアの平均值は $\delta$ に対 して明確な単調増加関数となり, 不安定相では $\delta$ に対し て，ばらつきは大きいものの減少する傾向となるか，も しくはほぼ一定の範囲となる .

$\mathrm{KE}$ モデルでは実験を行ったすべての設定について不 安定相が観察された . 兴の他の構造では， $\langle k\rangle$ が小い 場合，もしくは $\bar{X}$ がさい場合に限って不安定相が発現 

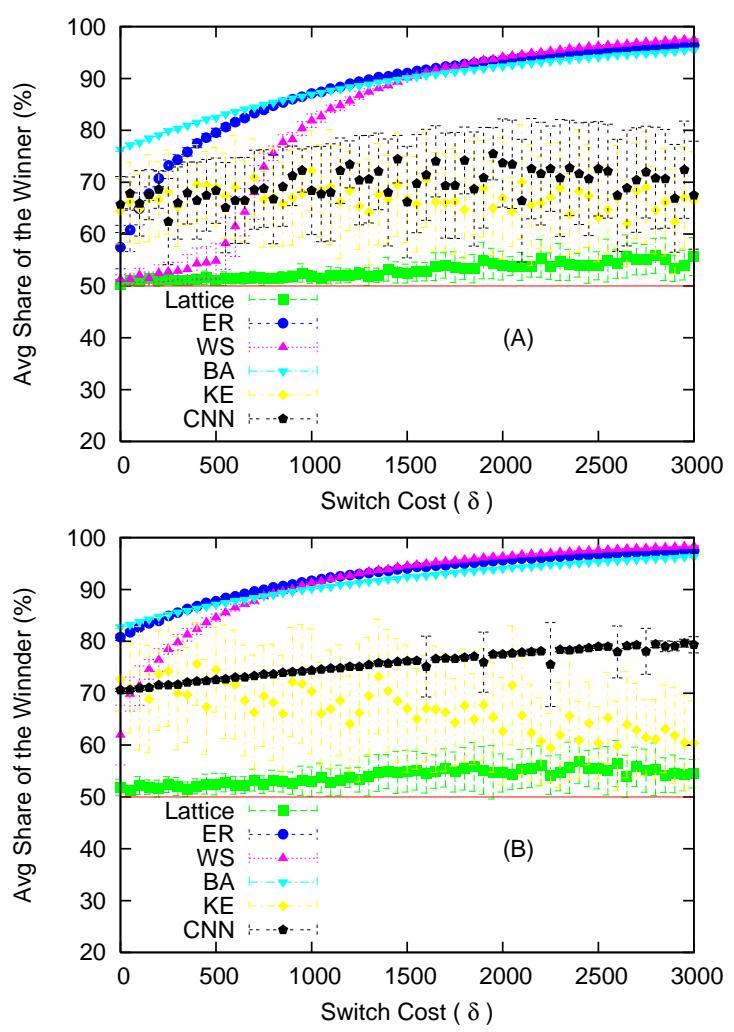

図 6 準安定状態における勝者のシェア.(モデル II , 誤差棒は 100 回の試行における標準偏差をあらわす. $\bar{X}=100, \alpha_{S}=20$, $\alpha_{D}=25,(\mathrm{~A})\langle k\rangle=8$, (B) $\langle k\rangle=10$.)

し，光の他の場合は安定相をとる.クラスタリング係数 の低い ER モデルと BA モデルの構造では, 強いネット ワーク外部性の効果が作用するのはモデル I による実験 結果と同樣だが , クラスタリング係数が高く，モデル I では外部性の作用か弱かった WS モデルでも，モデル II では外部性が強く作用する . 特に, 図 7(A)の設定では， WS モデルと CNN モデルで, $\delta$ の増加につれて , 自明 ではない $\delta$ の值で安定相から不安定相に移行する樣子が

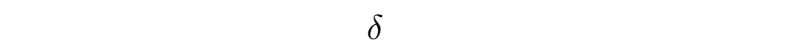
とる。

$3 \cdot 3$ 実際のネットワークを用いたシミュレーション

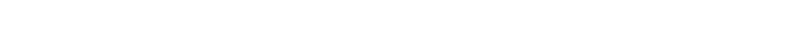
れのネットワークの性質に対して，異なる市場の振る舞 いが発現することがわかった，弚れらの結果を，現実の コミュニケーションネットワークの構造データを用いた 数值実験での結果と比較する. 弚して, ネットワーク外 部性の効果に対して複雑ネットワークモデルを導入する ことの有効性，および実際の市場のネットワークモデル として再現性の高いモデルについて考察する．

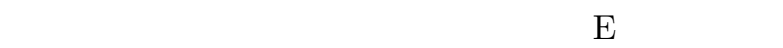
信のネットワークの実データを比証のために用いる ${ }^{* 5}$.こ

\footnotetext{
$* 5$ このデータは

http://deim.urv.cat/\%7Eaarenas/data/welcome.htm で公開されている.
}
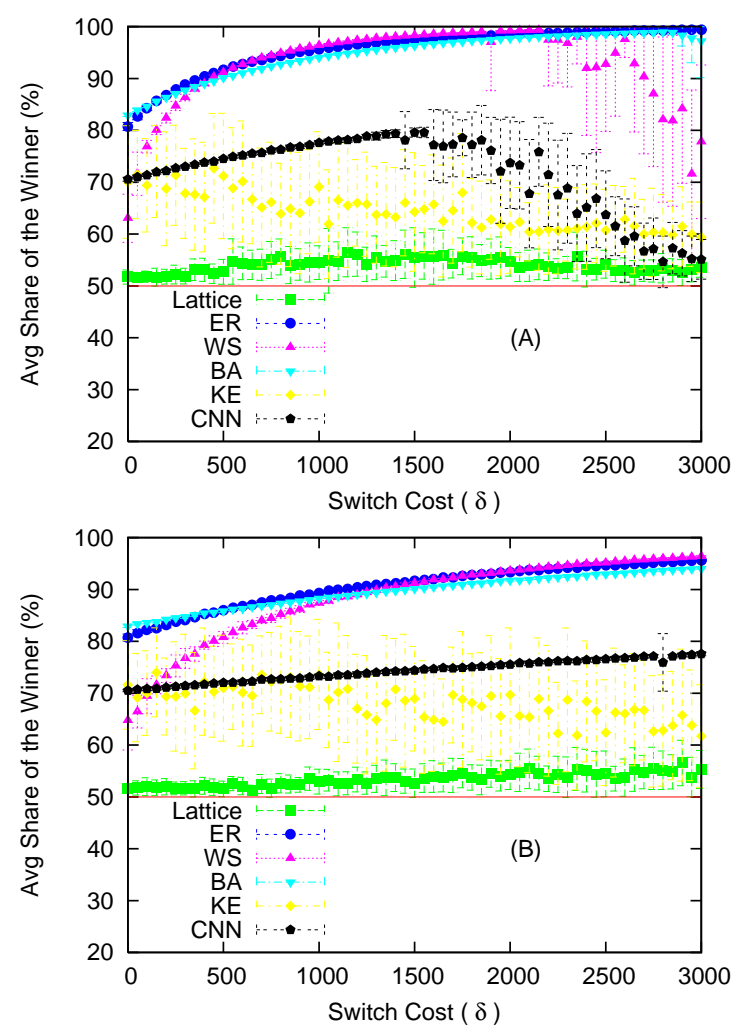

図 7 準安定状態における勝者のシェア .(モデル II , 誤差棒は 100 回の試行における標準偏差をあらわす . $\langle k\rangle=10, \alpha_{S}=20$, $\alpha_{D}=25$, (A) $\bar{X}=50$, (B) $\bar{X}=150$.)

のデータは文献 [Guimerà 03] で分析されたものであり， スペインのある大学 (University Rovira i Virgili) にお

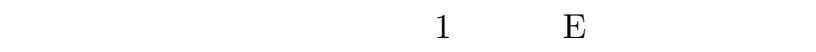
りがあったペアにエッジを定義したものである.1133人 (ノード) に5451 本のエッジが定義されている.平均次数 は $\langle k\rangle=9.62$ である.クラスタリング係数は $C=0.254$ であり, 同程度のノード数およびエッジ数のランダムネッ トワークより 10 倍程度大きい . 平均経路長は $L=3.606$ である.また，次数分布は指数分布に従うことが報告さ れている [Guimerà 03] .

図 8 および図 9 に,このネットワーク構造を導入し，

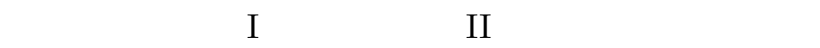
ンの結果を示す . 以下の点について , ネットワークモデ ルを導入したシミュレーションと同樣の結果を得ている．

・モデル I で, $\bar{X}$ が大きくなるにしたがって同じ乗り 換えコスト $\delta$ に対する外部性の作用か強くなる点 .

・モデル II で, 安定相と不安定相が観察される点 .

・モデル II で, 特定の $\delta$ を境に安定相から不安定相に 転移し, 弚のような $\delta$ で外部性の作用か極大值を取 る点 .

特に，モデルIの場合に，比較的大きな $\delta$ に対しても外部 性の作用が比較的緩やかに低下する様子や，モデル II の 場合に，比較的近いパラメータで明確な極大値と，安定 相から不安定相への転移が見られる樣子から，CNN モデ 


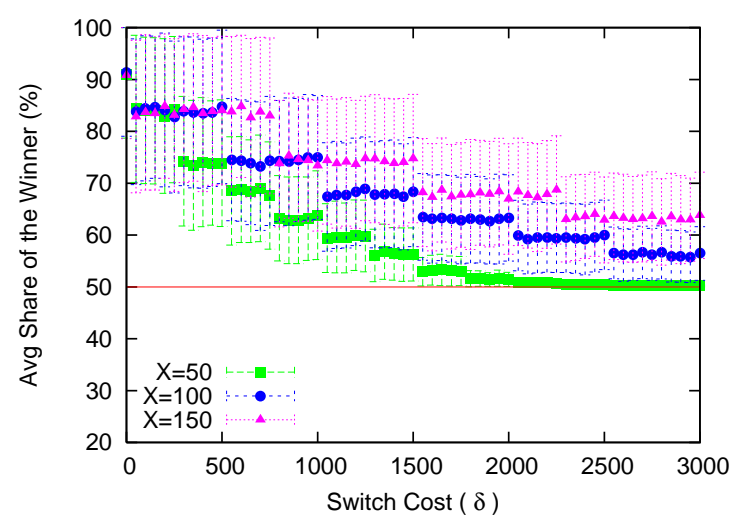

図 8 準安定状態における勝者のシェア.(モデル I , 誤差棒は 500 回 の試行における標準偏差をあらわす . $\alpha^{S}=20, \alpha^{D}=25$.)

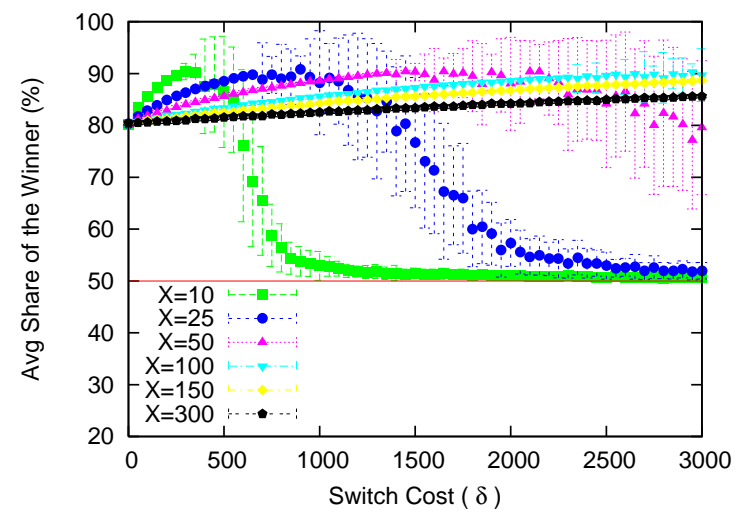

図 9 準安定状態における勝者のシェア.(モデル II , 誤差棒は 100 回の試行における標準偏差をあらわす . $\alpha^{S}=20, \alpha^{D}=25$.)

ルを用いたシミュレーションにおける結果と類似性が見 られる .この実データと CNN モデルでは, 次数分布の 形状か指数分布とべき乗分布で異なっているほか，CNN モデルは平均経路長が比較的大きい，また，同程度の $C$, 同程度の $L$ を持つ他のネットワークモデルでも，実デー タとは大きく異なるシミュレーション結果を得ている.こ れらの結果より，より再現性の高いシミュレーションを 行うという観点からは, コミュニケーションネットワー クのモデルとして適切なネットワークモデルを導入する ことの重要性が示される.

\section{4. 考察および議論}

本章では,ネットワークモデル，および実データを用 いた数値実験から得られた結果について考察する .

モデル I の場合，乗り換え費用 $\delta$ が小さい領域では， $\mathrm{ER}$ モデルと BA モデルにおいて外部性が強く働き，市 場の大部分が一方の事業者を利用するという現象か観察 される.これらのネットワークに共通する性質は, クラス タリング係数が小さいことである. 逆に, クラスタリン グ係数が高いネットワークでは,「友人の友人」同士が比 較的密につながっているため, 互いに隣接している利用
者同士で同じサービスの利用価値を向上させ , 局所的に バランスしているものと考えられる . しかし , モデル II では, クラスタリング係数が高いWS モデルでも強い外 部性の作用が観察される。このことから，エージェント のコミュニケーション量にばらつきがある場合には, ク ラスタ性の効果が限定的になるものと考えられる .

一方で, 次数分布のスケールフリー性, 高いクラスタ リング係数，短い平均経路長という特徵を共有する $\mathrm{KE}$ モデルと CNN モデルでは，モデル I ， モデル II のいず れにおいても，CNN モデルのほうに強い外部性の作用 が認められる .このことから, $\mathrm{CNN}$ モデルの特徵であ る正の次数相関が , 外部性の作用を押し上げる効果があ ると考えられる .

また，モデル II では, 特定の $\delta$ の值で外部性の作用 か極大値をとる．本論文で提案したシミュレーションモ デルのパラメータのうち， $\alpha^{S}, \alpha^{D}, \delta$ は事業者の料金 設定や，サービス仕樣によって決定することができるパ ラメータである．本論文で提案したようなモデルを用い， 適切な相互作用ネットワークを導入してシミュレーショ ンを行い，このような極大値を探索することで，市場に 作用する外部性の効果を見積もった上で，事業者がシェ ア向上のための戦略的に最適なパラメータや, 市場全体 の効率性を向上させるためのパラメータを決定すること に対する支援が可能となると考えられる．

実データを用いた数值実験では，CNN モデルにおける 結果と類似した結果が得られている.次数分布はべき乗 分布と指数分布で異なるものの, いずれもピークを持た

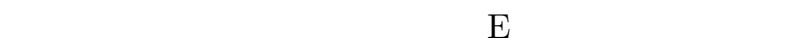
ワークにおける高いクラスタリング係数, 短い平均経路 長といった構造の特徵は CNN モデルでも再現している． このように，実際の市場における相互作用ネットワーク 構造を，適切なネットワークモデルによって特徴を再現 することにより，相互作用の構造として格子やランダム ネットワークを用いた従来のモデル化では捨象していた 部分を含めて，市場の振る舞いをより詳細に分析し，乥 の後の施策，戦略立案を支援することが可能になるもの であると考えられる .

\section{5. 関 連 研 究}

従来のネットワーク外部性に対する分析的な研究の多 くは, 製品のシェアに代表されるマクロ統計量的な指標 にもとづく数理的解析 [Church 92, Katz 92, Arthur 93] や比較的小規模な被験者実験による実証的な分析である 例えば, 消費者数, 購入者数, 製品を嗜好する消費者の 数, 製品価格, 留保価格から効用関数を定め, 効用関数 にもとづいて，均衡分析やゲーム理論からの均衡解を求 める . 利用者間の複雑な相互作用をモデル化したものは 少ないが，相互作用を簡素化し，エージェントモデルに よって分析を試みるものもある [Frels 03, Khalak 03, 川 
村 05 , 金子 06].

人工市場シミュレーションの手法を用いてネットワーク 外部性を分析する上でも, 利用者間のネットワークの影響 に着目するものがある.Wendt らは，ネットワーク外部 性の分析において，消費者間の情報伝播を明らかにする必 要性を主張し，独自に定義した connectivity, closeness， centralityというパラメータによって，消費者間の相互作 用ネットワークをモデル化した [Wendt 00, Weitzel 02] . 乥して，消費者間の情報伝播に影響を与えるネットワー クの性質を明らかにすることを試みている．なお，生成 されるネットワークは, ランダムネットワークを拡張し たものである . connectivity, closeness, centrality は, 本論文で述べた複雑ネットワーク研究で用いられる指標 とは異なり，Wendt らが独自に定義したものである．し たがって, 現実世界の相互作用が生じるネットワークが もつ特徵的な構造を直接再現することを意図したもので はない . [川村 05] では, 格子, ランダムネットワーク， WS モデル，BA モデルを用い，相互作用をもたらすネッ トワークの構造の違いによって, 市場の振る舞いに違い が生じ，光の結果マーケッティングを行う際に企業がと るべき戦略が異なることを指摘している．しかしながら， ネットワーク構造の違いが結果に与える影響を詳細に分

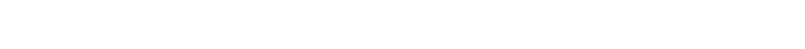
ワークの統計的指標の特徵と結果を結びつけた十分な考 察がなく，現実のネットワークデータとの対応付けも行 われていないという点で本研究とは視点が異なる.

一方, 近年になって大規模なコミュニケーションネット ワークの実データを対象とする構造分析もさかんに行わ れている.本研究でデータを用いた電子メールによる通 信ネットワーク以外にも, 別の電子メール通信ネットワー クの分析 [Ebel 02, Kossinets 06] や , 携帯電話の音声通 話および文字メッセージによるコミュニケーションネット ワークの大規模な分析が行われている [Palla 07, Onnela 07, Hidalgo 08] . 特に後者では, 実際の携帯電話事業者 から提供された 400 万以上の利用者の利用履歴に関する 大規模なデータを分析対象としている，我が国でも，通信 トラフィックのシミュレーションモデルの構築のために , 携帯電話事業者による利用者の通信ログのネットワーク 分析事例 [佐々木 05 , 秋永 $06 \mathrm{a}]$ や，弚れをもとに戦略的 な広告手法について考察した研究 [秋永 06b] がある.

このような実際の市場におけるコミュニケーションネッ トワークの研究事例を, 本研究で提案した人工市場アプ ローチによる市場ダイナミクスの分析と組み合わせるこ とで, 複雑な市場現象のさらなる理解につながるものと 期待される .

\section{6. 結言}

本論文では，利用者間のコミュニケーションサービス の市場に作用するネットワーク外部性の効果を，2 種類
の利用者モデル，および利用者間のコミュニケーション の空間構造を複雑ネットワークモデルによってモデル化 した人工市場シミュレーションによって分析した．弚の 結果, コミュニケーションネットワークの空間構造によっ て, 市場に作用するネットワーク外部性の強さに差異が 生じることを確認し, 平均次数 (密度) に加え, クラス 夕性, 正の次数相関が, 外部性の作用を強める主要な要 因となることを指摘した . また , 実際のコミュニケーショ ンネットワークを導入したシミュレーションからは，乥 れらの要因を適切に再現したネットワークモデル (本論 文で分析したモデルの中では CNN モデル) によって，現 実に起こりうる市場現象をより正確に再現し, 評価が可 能となることを示した .

さらに，2 種類の利用者モデルの違いから，利用者の ミクロレベルのモデリングの違いによる，市場全体に発 現するネットワーク外部性の作用の差異を示した . 特に， 利用者のコミュニケーション量に不均一性を導入したモ デル II において, 市場全体の振る舞いに安定相と不安定 相の 2 相が発現することを示した . 乥れらは背後のネッ トワーク構造と乗り換えコストのパラメータ設定に依存 し，特定のパラメータで極大值をとることを示した .こ れらの知見から，事業者が利用者の相互作用ネットワー クの構造を分析することで, 市場に作用するネットワー ク外部性の効果を適切に見積もり, 自社にとって最適な サービス仕樣や料金の設定をするための支援となるもの と期待できる .

今後，これらの結果を害際のコミュニケーションネッ トワークデータ, および実際の利用者のサービス利用パ ターンのモデル等と比較することで, 本論文で行ったシ ミュレーションの妥当性を検証するとともに，利用者の ネットワーク構造の分析を通じて，マーケッティングや サービス効果の向上を図るための一助となる知見につい て，さらに考察してゆきたいと考えている．

\section{謝 辞}

本論文の執筆にあたり，有意義な議論およびアドバイ スをいただいたNTTドコモ総合研究所の秋永和計氏，金 田茂氏，佐々木純氏，山崎憲一氏および NTT 未来ねつ と研究所の風間一洋氏に謝意を表する．また，本研究の 一部は科研費 (特別研究員奨励費, 課題番号 $20 \cdot 3782$ ) の助成を受け行った .

\section{$\diamond$ 参 考 文 献 $\diamond$}

[Arthur 90] Arthur, W. B.: Positive feedbacks in the economy, Scientific American, Vol. 262, pp. 92 - 99 (1990)

[Arthur 93] Arthur, W. B. and Lane, D. A.: Information Contagion, Structural Change and Economic Dynamics, Vol. 4, pp. 81 - 104 (1993)

[Arthur 96] Arthur, W. B.: Increasing returns and the new world of business, Harvard Business Review, Vol. July-Aug., (1996) 
[Barabási 99] Barabási, A.-L. and Albert, R.: Emergence of scaling in random networks, Science, Vol. 286, pp. 509-512 (1999)

[Boccaletti 06] Boccaletti, S., Latora, Y., Moreno, Y., Chavez, M., and Hwang, D.-U.: Complex networks: Structure and dynamics, Physics Report, Vol. 424, pp. $175-308$ (2006)

[Church 92] Church, J. and Gandal, N.: Network Effects, Software Provision and Standardization, The Journal of Industrial Economics, Vol. 40, No. 1, pp. 85 - 103 (1992)

[Ebel 02] Ebel, H., Mielsch, L.-I., and Bornholdt, S.: Scalefree topology of e-mail networks, Physical Review E, Vol. 66, No. 035103 (2002)

[Erdös 59] Erdös, P. and Rényi, A.: On random graphs, Publicationes Matematicae, Vol. 6, pp. 290 - 297 (1959)

[Frels 03] Frels, J. K., Heisler, D., and Geggia, J. A.: Standard-scope: an agent-based model of adoption with incomplete information and network externalities, in Proceedings of 3rd International Workshop on CIEF, pp. 1219 $-1222(2003)$

[Guimerà 03] Guimerà, R., Danon, L., Díaz-Guilera, A., Giralt, F., and Arenas, A.: Self-similar community structure in a network of human interactions, Physical Review E, Vol. 68, No. 065103 (2003)

[Hidalgo 08] Hidalgo, C. A. and Rodriguez-Sickert, C.: The dynamics of a mobile phone network, Physica A, Vol. 387, pp. 3017 - 3024 (2008)

[Katz 85] Katz, M. L. and Shapiro, C.: Network Externalities, Competition, and Compatibility, American Economic Reviews, Vol. 75, No. 3, pp. $424-440$ (1985)

[Katz 92] Katz, M. L. and Shapiro, C.: Product Introduction with Network Externalities, The Journal of Industrial Economics, Vol. 40, No. 1, pp. 55 - 83 (1992)

[Khalak 03] Khalak, A.: Agent-based model for economic impact of free software, Complexity, Vol. 8, pp. $45-55$ (2003)

[Klemm 02] Klemm, K. and Eguíluz, V. M.: Highly clustered scale-free networks, Physical Review E, Vol. 65, No. 036123 (2002)

[Kossinets 06] Kossinets, G. and Watts, D. J.: Empirical Analysis of an Evolving Social Network, Science, Vol. 311, No. 5757, pp. 88 - 90 (2006)

[Lee 06] Lee, E., Lee, J., and Lee, J.: Reconsideration of the Winner-Take-All Hypothesis: Complex Networks and Local Bias, Management Science, Vol. 52, No. 12, pp. $1838-1848$ (2006)

[Newman 06] Newman, M. E. J., Barabási, A.-L., and Watts, D. J.: The Structure and Dynamics of Networks, Princeton Univ. Press (2006)

[Onnela 07] Onnela, J.-P., Saramäki, J., Hyvönen, J., Szabó, G., Lazer, D., Kaski, K., Kertész, J., and Barabási, A.-L.: Structure and tie strengths in mobile communication networks, Proceedings of National Academy of Science, Vol. 104, pp. 7332 - 7336 (2007)

[Palla 07] Palla, G., Barabási, A.-L., and Vicsek, T.: Quantifying social group evolution, Nature, Vol. 446, pp. $664-$ 667 (2007)

[Phan 03] Phan, D., Pajot, S., and Nadal, J. P.: The monopolist's market with discrete choices and network externality revisited: small-worlds, phase transition and avalanches in an ACE framework, in Proceedings of the Ninth annual meeting of the Society of Computational Economics (2003)

[Vázquez 03] Vázquez, A.: Growing network with local rules: Preferential attachment, clustering hierarchy, and degree correlations, Physical Review E, Vol. 67, No. 056104 (2003)

[Watts 98] Watts, D. J. and Strogatz, S. H.: Collective dynamics of 'small-world' networks, Nature, Vol. 393, pp. 440 -442 (1998)

[Weitzel 02] Weitzel, T., Wendt, O., and Westarp, F.: Reconsidering network effect theory, in Proceedings of the 8th European Conference of Information Systems, pp. 484-491
(2002)

[Wendt 00] Wendt, O. and Westarp, v. F.: Determinants of Diffusion in Network Effect Markets, in SFB 403 Research Report (2000)

[秋永 06a] 秋永 和計, 金田 茂, 井原 武, 品川準輝, 三浦 章 : モ バイルネットワークシミュレーションのためのユーザ情報通信 モデルの提案, 電子情報通信学会技術研究報告. NS, ネットワー クシステム, Vol. 105, No. 627, pp. 197-200 (2006)

[秋永 06b] 秋永 和計, 佐々木 純, 井原武, 品川準輝, 三浦 章 : コミュニケーションサービスにおける戦略的広告方法の提案, 電 子情報通信学会総合大会講演論文集, No. 2, p. 260 (2006)

[和泉 03] 和泉 潔 : 人工市場 -市場分析の複雑系アプローチ-, 森 北出版 (2003)

[井庭 01] 井庭 崇, 竹中 平蔵, 武藤 佳恭: 人工市場アプローチに よる家庭用 VTR の規格競争シミュレーション, 情報処理学会 論文誌: 数理モデル化と応用, Vol. 42, No. SIG14, pp. 73 - 89 (2001)

[井庭 03] 井庭 崇: 社会・経済シミュレーションの基盤構築 一複 杂隹系と進化の理論に向けて一, PhD thesis, 慶応義塾大学大学院 政策・メディア研究科 (2003)

[金子 06] 金子 陽平, 西野 成昭 : ネットワーク外部性をともな う市場における情報非対称性と購買行動, 情報処理学会論文誌, Vol. 47, No. 5, pp. 1473 - 1482 (2006)

[川村 05] 川村 秀憲, 大内 東 : ネットワーク外部性の働く製品市 場のモデル化とプレゼント戦略の評価, 日本オペレーションズ . リサーチ学会和文論文誌, Vol. 48, pp. 48 - 65 (2005)

[佐々木 05] 佐々木 純, 秋永 和計, 井原 武 : 携帯電話における ユーザ間ネットワーク構造分析, 電子情報通信学会ソサイエティ 大会講演論文集, No. 2, p. 168 (2005)

〔担当委員 : 栗原 聡〕

2008 年 5 月 11 日 受理

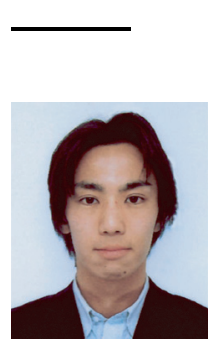

者 紹 介

\section{内田誠}

東京大学大学院工学系研究科博士課程.日本学術振興会特 別研究員 (DC2). 2006 年東京大学工学系研究科噮境海 洋工学専攻修士課程修了. 同年東京大学人工物工学研究七 ンター学術研究支援員を経て, 同年 10 月より現所属. 複 雑系シミュレーション, 複雑ネットワークの構造およびダ イナミクスの分析・可視化に関する研究に従事. 情報処理 学会, 電子情報通信学会, 日本機械学会会員.

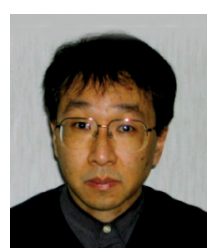

\section{白山 晋(正会員)}

1982 年京都大学工学部航空工学科卒業. 1987 年東京大 学工学系航空学専攻博士課程修了. (株) 計算流体力学研 究所などを経て,1999 年東京大学工学系研究科環境海洋工 学専攻助教授. 2002 年, 同大学人工物工学研究センター 助教授. 2007 年同准教授, 現在に至る. 工学博士. 主と して, 複雑ネットワーク分析, 可視化情報に関する研究に 従事。 